\title{
Communication
}

\section{Cu-catalyzed deoxygenative gem-hydroborylation of aromatic aldehydes and ketones to access benzylboronic esters}

\author{
Lu Wang a, Wei Sun a,b, Chao Liu a,* \\ a State Key Laboratory for Oxo Synthesis and Selective Oxidation, Suzhou Research Institute of Lanzhou Institute of Chemical Physics (LICP), LICP, \\ Chinese Academy of Sciences, Lanzhou 730000, Gansu, China \\ ${ }^{\mathrm{b}}$ University of Chinese Academy of Sciences, Beijing 100049, China
}

\section{A R T I C L E I N F O}

\section{Article history:}

Received 13 June 2018

Accepted 15 July 2018

Published 5 November 2018

\section{Keywords:}

Homogeneous catalysis

Copper catalysis

Deoxygenative gem-hydroborylation

Aromatic aldehydes

Aromatic ketones

\begin{abstract}
A B S T R A C T
Organoboron compounds are widely used in synthetic chemistry, pharmaceutical chemistry and material chemistry. Among various organoboron compounds, benzylboronic esters are unique and highly reactive, making them suitable benzylation reagents. At present, the synthetic methods for the syntheses of benzylboronic esters are still insufficient to meet their demands. It is necessary to develop novel and practical methods for their preparation. In this work, a novel copper-catalyzed deoxygenative gem-hydroborylation of aromatic aldehydes and ketones has been developed. This direct and operationally simple protocol provides an effective approach for the synthesis of a variety of primary and secondary benzylboronates, in which broad functional group tolerance was presented. Widely available $\mathrm{B}_{2} \mathrm{pin}_{2}$ (pin = pinacol) was used as the boron source and alcoholic proton was applied as the hydride source.
\end{abstract}

(C) 2018, Dalian Institute of Chemical Physics, Chinese Academy of Sciences. Published by Elsevier B.V. All rights reserved.
Organoboron compounds represent significant structural motifs in organic synthesis [1-6], developing novel and practical strategies for the synthesis of organoboron compounds is highly demanding in nowadays chemical society. Among various organoboron compounds, benzylboronic esters are unique alkylboron compounds. They are relatively reactive and can be a practical benzylation reagent in the presence of transition metal catalysts [7-14]. Up to date, tremendous efforts have been made for the synthesis of benzylboronic esters. In general, benzylboronic esters are often synthesized by the borylation of Grignard or lithium reagents [15]. However, this method shows poor functional group compatibility and the difficult preparation of benzylic Grignard and lithium reagents make this classic approach less practical. Recently, transition metal (including
$\mathrm{Pd}, \mathrm{Cu}, \mathrm{Ni}, \mathrm{Fe}$, et al.) catalyzed borylation of benzyl (pseudo)halides has been reported for the synthesis of benzylboronic esters [14,16-22]. Moreover, the cross-coupling of aryl halides [23,24] or sulfonates [25] with 1,1-diborylalkanes under palladium catalysis is also an effective method. Benzylic alcohols have also been utilized as electrophiles for the synthesis of primary benzylic boronic esters in the presence of palladium or copper catalyst $[26,27]$, in which secondary benzylic alcohols cannot be compatible in those catalytic system. Directly utilizing benzylic $\mathrm{C}-\mathrm{H}$ as the electrophile under the transition metal catalyzed borylation condition is an ideal approach, while it currently still suffers from the chemoselectivity issues on benzylic or aromatic $\mathrm{C}-\mathrm{H}$ borylation and mono- or di-borylation [28-30]. Styrenes could also be used for the syn-

\footnotetext{
* Corresponding author. E-mail: chaoliu@licp.cas.cn

This work was supported by the National Natural Science Foundation of China (91745110, 21673261, 21603245, 21633013, 21703265) and a Start-up funding from LICP. Support from the Young Elite Scientist Sponsorship Program by CAST, CAS Interdisciplinary Innovation Team, the Key Program of CAS (QYZDJ-SSW-SLH051), the Youth Innovation Promotion Association CAS (2018458) and the 'Light of West China' Program. DOI: 10.1016/S1872-2067(18)63139-0 | http://www.sciencedirect.com/science/journal/18722067 | Chin. J. Catal., Vol. 39, No. 11, November 2018
} 


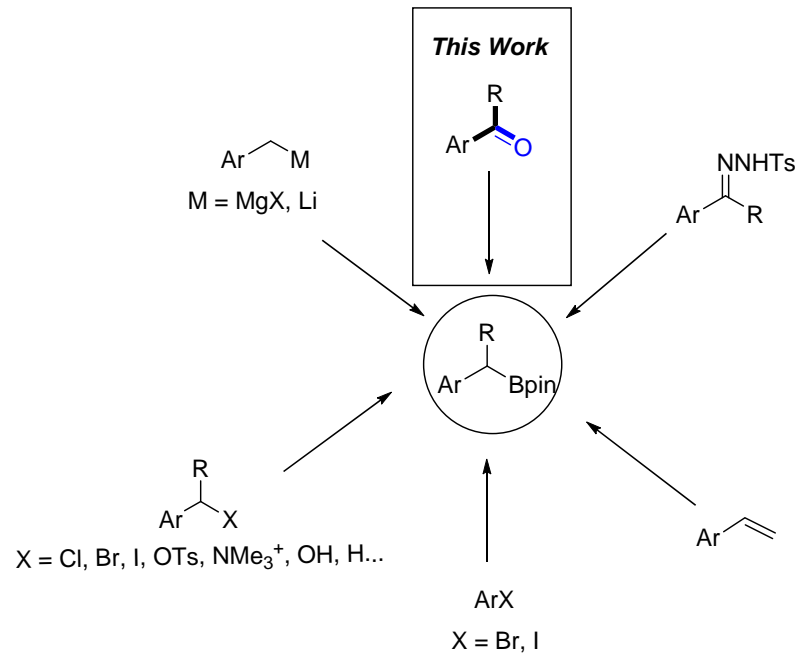

Scheme 1. Strategies for the synthesis of benzylboronic esters.

thesis of benzylboronic esters via unusual transition metal catalyzed Markovnikov selective hydroborations [31-37]. Through 1,2-metelate rearrangement, benzylboronic esters could be synthesized from tosylhydrazones and HBpin or B2pinz under a metal-free condition [38]. Tosylhydrazones are usually prepared from carbonyl compounds. The direct utilization of aromatic carbonyls for the synthesis of benzylboronic esters would be more step-economy [39]. Herein, we describe the first deoxygenative gem-hydroborylation of aromatic aldehydes and ketones under copper catalysis to access both primary and secondary benzylboronic esters (Scheme 1).

In 2017, we have demonstrated a deoxygenative gem-diborylation of aliphatic aldehydes and ketones [40]. During this study, when benzaldehyde (1a) was utilized as the substrate, a significant amount of gem-hydroborylation product benzylboronic ester (2a) was obtained instead of gem-diboron product. These initial results promoted us to further improve the preparative procedure by using $\mathrm{MeOH}$ as the $[\mathrm{H}]$ source for achieving the catalytic synthesis of benzylboronic esters from aromatic aldehydes. As a result, 2a was isolated with $71 \%$ yield under an optimal catalysis system: $\mathrm{ICyCuCl}(5 \mathrm{~mol} \%), \mathrm{B}_{2} \mathrm{pin}_{2}$ (2.2 equiv.), $\mathrm{NaO}{ }^{t} \mathrm{Bu}$ (1.3 equiv.), with $\mathrm{MeOH}$ (1.0 equiv.) as the proton source in hexane at $100^{\circ} \mathrm{C}$ for $5 \mathrm{~h}$ (Scheme 2).

With the optimized conditions in hand, a wide range of aromatic aldehydes were first examined for its generality in this transformation. As shown in Scheme 3, the reaction system is efficient for substrates containing various functional groups and afford the corresponding products in moderate to good

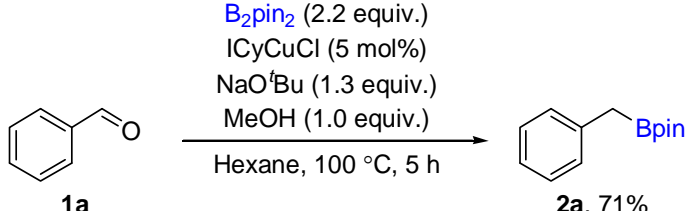

Scheme 2. The deoxygenative gem-hydroborylation of benzaldehyde.

yields. For instance, the reaction of substrates with electron-donating groups $\left(-\mathrm{OMe},-{ }^{t} \mathrm{Bu}\right.$ or other oxygen-containing groups) and substrates with electron-withdrawing groups $(-\mathrm{F}$ and $-\mathrm{Cl}$ ) all proceeded well, affording the corresponding products in moderate to good yields (2b-2e, $\mathbf{2 g}, \mathbf{2 i}-\mathbf{2 m})$. The sulfur-containing group -SMe was also tolerated under standard condition (2f). It was noteworthy that steric effect did not have a strong influence on the reactivity. For instance, when 2,4,6-trimethylbenzaldehyde was used as the substrate, the corresponding product $\mathbf{2 h}$ was isolated in $52 \%$ yield. Moreover, other aromatic aldehyde such as 2-naphthaldehyde and hetero-aromatic aldehyde such as 2-thenaldehyde proceeded smoothly to generate the corresponding products $(\mathbf{2 n}, \mathbf{2 0})$.

However, when extending the catalytic system to aromatic ketones, problem occurred and only trace amounts of products were detected, in which most of the starting ketones were reduced to their corresponding alcohols. The generation of alcohols indicated the presence of hydride species in this catalytic system. It has been demonstrated that proton could be used as hydride source in the presence of $\mathrm{B}_{2} \mathrm{pin}_{2}$ [41-49]. Furthermore, Clark et al. [50] has shown that the addition rate of a copper-boron species to ketone $\mathrm{C}=0$ group was slower than that of aldehydes. Therefore, the addition of hydride species to ketone carbonyls dominated the transformation of ketones. As a result, alcohols were produced as the major products. In order to solve this problem, a more reactive $\mathrm{KO}^{t} \mathrm{Bu}$ was applied to activate $\mathrm{B}_{2}$ pinz instead of $\mathrm{NaO}^{t} \mathrm{Bu}$, for which we expected to increase the nucleophilicity of boryl group for the addition to ketone carbonyl groups. Meanwhile, a less acidic alcohol was utilized as the proton source instead of $\mathrm{MeOH}$, for which we expected to slower down the generation of hydride species. To our delight, after a series of attempts, when the reaction was carried out in the presence of 1.0 equiv. $\mathrm{KO}{ }^{t} \mathrm{Bu}$ as base and EtOH as the proton source, the aromatic ketones were successfully transformed to their corresponding secondary benzylboronic esters.

Subsequently, a series of aromatic ketones were investigated under the optimized conditions (Scheme 4). Aromatic ketones, such as acetophenone, propiophenone and butyrophe-

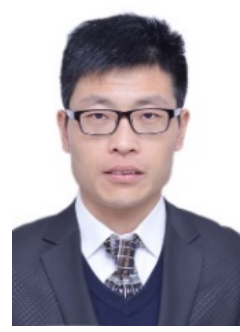

Chao Liu (Lanzhou Institute of Chemical Physics, Chinese Academy of Sciences (CAS)) received the Catalysis Rising Star Award in 2017, which was presented by The Catalysis Society of China. Chao Liu (1985) obtained his B.Sc (2007) and Ph.D. (2012) at Wuhan University under the supervision of Prof. Aiwen Lei. After his postdoctoral research at Wuhan University, he started his independent career in 2015 at Suzhou Research Institute of LICP, Lanzhou Institute of Chemical Physics (LICP), CAS. He is a member of the Youth Innovation Promotion Association, CAS and was selected for the Young Elite Scientist Sponsorship Program by CAST. His group is now focusing on organoboron chemistry and carbonyl chemistry. 


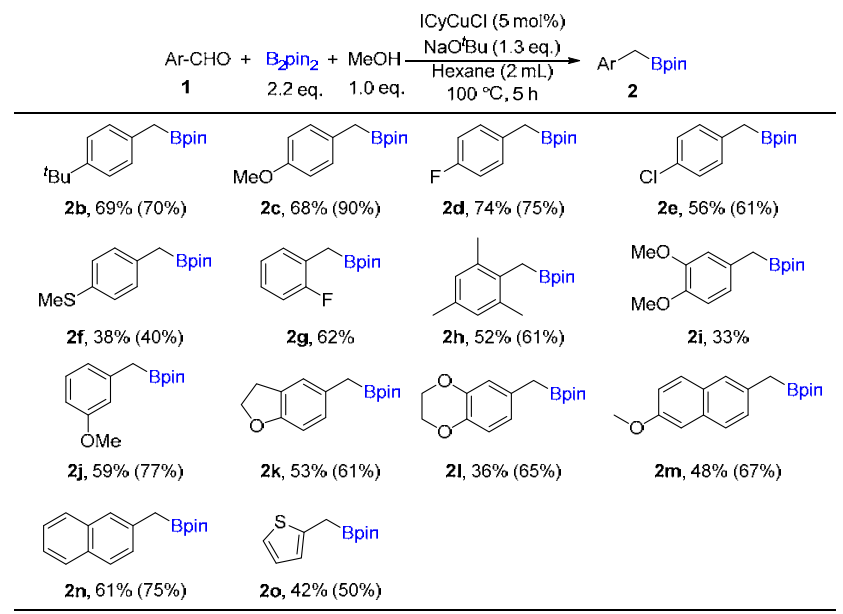

Scheme 3. Deoxygenative gem-hydroborylation of aldehydes. Reaction conditions: $\mathbf{1}$ ( $0.5 \mathrm{mmol}), \mathrm{B}_{2} \mathrm{pin}_{2}(1.1 \mathrm{mmol}), \mathrm{MeOH}(0.5 \mathrm{mmol}), \mathrm{ICyCuCl}$ $(0.025 \mathrm{mmol}), \mathrm{NaO} \mathrm{Bu}^{\mathrm{B}}(0.65 \mathrm{mmol})$, hexane $(2.0 \mathrm{~mL}), 100^{\circ} \mathrm{C}, 5 \mathrm{~h}$. Isolated yields. ${ }^{1} \mathrm{H}$ NMR yields are shown in the parentheses using $\mathrm{CH}_{2} \mathrm{Br}_{2}$ as the internal standard, decomposition of products occurred through column chromatography.

none, could be smoothly transformed to the corresponding benzylboronic esters in moderate yields $(\mathbf{4 a}, \mathbf{4 b}, \mathbf{4 d}, \mathbf{4 e})$. Substrates bearing electron-rich group, such as $p$-methoxyacetophenone, have been evaluated and the desired product was obtained in moderate yield albeit prolonged reaction time was required $(\mathbf{4 c}, \mathbf{4 i})$. A significant amount of 1,1-diborylation products was detected by GC-MS if the reaction time was shortened to $1 \mathrm{~h}$. This interesting phenomenon indicated that the ketones may firstly transformed to 1,1-diborylakanes, followed by selective protodeboronation to afford the final products. Benzocycloanone can be smoothly converted into the desired products $(\mathbf{4 f}, \mathbf{4 g})$. 2-Acetonaphthone

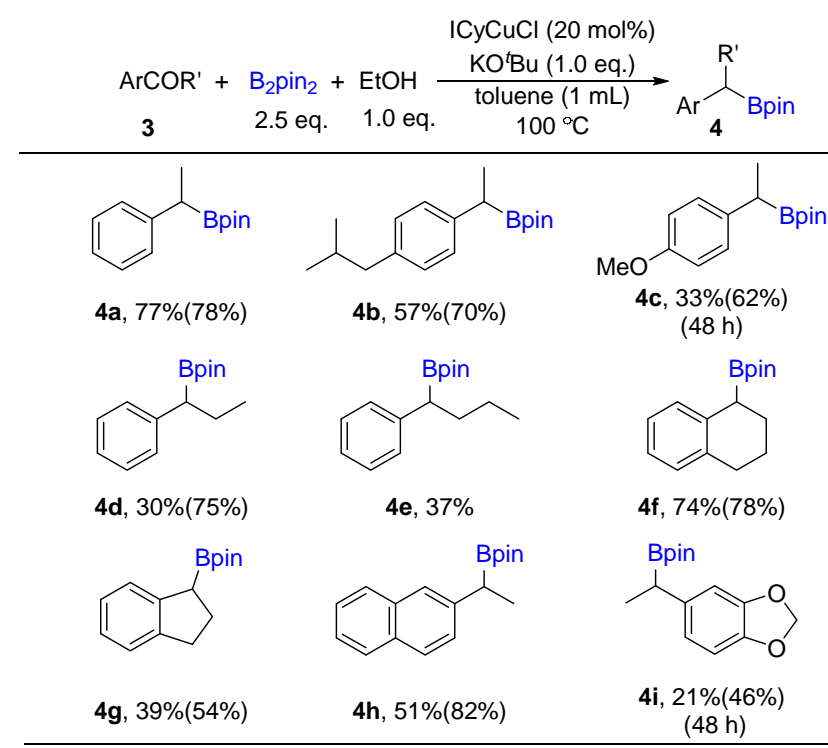

Scheme 4. Deoxygenative gem-hydroborylation of ketones. Reaction conditions: 3 (0.5 mmol), B $\mathrm{pin}_{2}(1.25 \mathrm{mmol}), \mathrm{EtOH}(0.5 \mathrm{mmol}), \mathrm{ICyCuCl}$ $(0.1 \mathrm{mmol}), \mathrm{KO}^{t} \mathrm{Bu}(0.5 \mathrm{mmol})$, toluene $(1.0 \mathrm{~mL}), 100{ }^{\circ} \mathrm{C}, 1-48 \mathrm{~h}$. Isolated yields. ${ }^{1} \mathrm{H}$ NMR yields are shown in the parentheses using $\mathrm{CH}_{2} \mathrm{Br}_{2}$ as the internal standard.

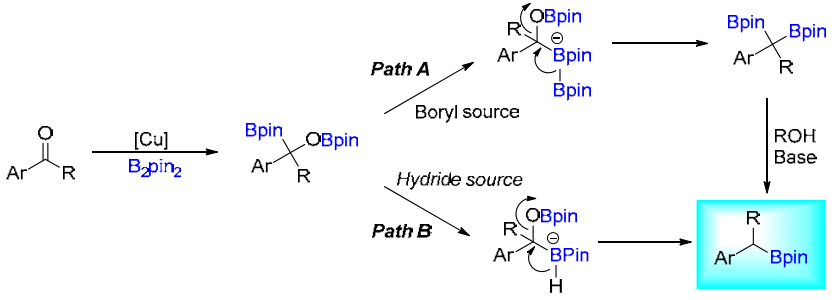

Scheme 5. Two proposed pathways for the deoxygenative gem-hydroborylation of aldehydes and ketones.

was also a suitable substrate to produce the corresponding product in moderate yields (4h).

Mechanistically, the copper-catalyzed 1,2-borylation of carbonyl was believed to initiate the reaction, in which $\alpha$-OBpin benzylboronic ester was generated. Our previous report and the results from the monitor of the reaction course demonstrated above exhibited that the borylation of $\alpha$-OBpin to give benzylic gem-diboron followed by protonation with alcohol is most likely the reaction mechanism (Scheme 5, Path A) $[38,40]$. In this case, the $\alpha$-OBpin containing tetracoordinated boron species with boryl as the migrating group was constructed. However, another pathway is also possible. As demonstrated above, there might be hydride species presented in the reaction system. Therefore, a tetracoordinated boron species with hydride as the migrating group would also generate the desired deoxygenative gem-hydroborylation product (Scheme 5, Path B).

To verify Path A, the benzylic gem-diboron 4a-1 was synthesized according to the literature [51]. Then it was subjected to react with $\mathrm{EtOH}$ in the presence of $\mathrm{KO}^{t} \mathrm{Bu}$. As a result, the protodeborylation product 4 a was obtained in $99 \%$ yield (determined by ${ }^{1} \mathrm{H}$ NMR analysis). In this case, catalytic amount of $\mathrm{KO}^{t} \mathrm{Bu}$ was used as the promotor, because of the $\mathrm{KO}^{t} \mathrm{Bu}$ was almost consumed in those standard reaction systems. This result indicated that the benzylic gem-diboron was presumed to be an intermediate in this transformation (Scheme 6, Eq. (1)). Next, in order to verify Path B, $\alpha$-OBpin benzylboronate 2a-1 was synthesized from benzaldehyde according to the literature [52]. Then it was subjected to react with $\mathrm{MeOH}, \mathrm{NaO}^{t} \mathrm{Bu}$ and $\mathrm{B}_{2}$ pin2 in hexane at $100{ }^{\circ} \mathrm{C}$ for $5 \mathrm{~h}$. As a result, the desired 2a was obtained in $47 \%$ yield, indicating the generation of

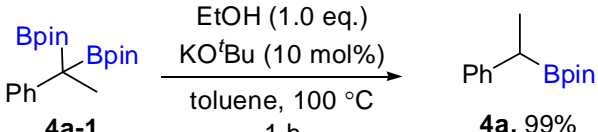

$$
\begin{aligned}
& 1 \mathrm{~h} \\
& \mathrm{MeOH} \text { (1.0 eq.) } \\
& \mathrm{B}_{2} \mathrm{pin}_{2} \text { (1.0 eq.) }
\end{aligned}
$$

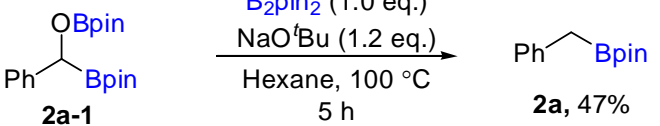

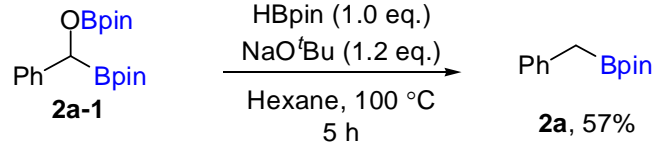

Scheme 6. Control experiments. 
$\alpha$-OBpin benzylboronate as an intermediate in this transformation (Scheme 6, Eq. (2)). Furthermore, HBpin was applied as the hydride source to test the hydride-migration hypothesis (Scheme 6, Eq. (3)). 2a-I was converted to the desired 2a smoothly in the presence of $\mathrm{HBpin}$ and $\mathrm{NaO}^{t} \mathrm{Bu}$ in $57 \%$ yield. This result indicated that the hydride-migration pathway is also possible for this transformation. Using $\mathrm{CD}_{3} \mathrm{OD}$ and HBpin resulted in a mixture of deuterated-2a and 2a (See supporting information for details), also indicated the possibilities of both pathways for this transformation. At current stage, either pathway could not be ruled out.

In summary, we have developed a straightforward and effective method for the synthesis of benzylboronic esters through $\mathrm{Cu}$-catalyzed deoxygenative gem-hydroborylation of readily available aromatic aldehydes and ketones. A series of substituted aryl aldehydes and ketones were successfully converted to their corresponding products. Alcoholic proton was utilized as the hydride source. At current stage, either boryl migration followed by protodeborylation or hydride migration is possible for the mechanistic consideration. Further detailed mechanism is currently underway in our laboratory.

\section{References}

[1] D. G. Hall, Boronic Acids: Preparation and Applications in Organic Synthesis, Medicine and Materials, 2nd completely rev. ed., Wiley-VCH, Weinheim, 2011.

[2] D. H. Tan, E. Lin, W. W. Ji, Y. F. Zeng, W. X. Fan, Q. Li, H. Gao, H. Wang, Adv. Synth. Catal., 2018, 360, 1032-1037.

[3] Q. Liu, B. Tian, P. Tian, X. Tong, G. Q. Lin, Chin. J. Org. Chem., 2015, $35,1-14$.

[4] Y. Qin, W. Xu, C. Hu, S. Liu, Q. Zhao, Chin. J. Inorg. Chem., 2017, 33, 1705-1721.

[5] J. Yang, Z. Li, S. Zhu, Chin. J. Org. Chem., 2017, 37, 2481-2497.

[6] Z. Yang, T. Cao, Y. Han, W. Lin, Q. Liu, Y. Tang, Y. Zhai, M. Jia, W. Zhang, T. Zhu, S. Ma, Chin. J. Chem., 2017, 35, 1251-1262.

[7] Y. Yasu, T. Koike, M. Akita, Adv. Synth. Catal, 2012, 354, 3414-3420.

[8] F. Lima, M. A. Kabeshov, D. N. Tran, C. Battilocchio, J. Sedelmeier, G. Sedelmeier, B. Schenkel, S. V. Ley, Angew. Chem. Int. Ed., 2016, 55,
14085-14089.

[9] K. Miyazawa, Y. Yasu, T. Koike, M. Akita, Chem. Commun., 2013, 49, 7249-7251.

[10] R. D. Grigg, J. W. Rigoli, R. Van Hoveln, S. Neale, J. M. Schomaker, Chem. Eur. J., 2012, 18, 9391-9396.

[11] J. C. Tellis, D. N. Primer, G. A. Molander, Science, 2014, 345, 433-436.

[12] G. A. Molander, N. Ellis, Acc. Chem. Res., 2007, 40, 275-286.

[13] V. Bagutski, T. G. Elford, V. K. Aggarwal, Angew. Chem. Int. Ed., 2011, 50, 1080-1083.

[14] A. Bej, D. Srimani, A. Sarkar, Green Chem., 2012, 14, 661-667.

[15] A. Pelter, K. Smith, H. C. Brown, Borane reagents, Academic Press, Newyork, 1998.

[16] S. K. Bose, S. Brand, H. O. Omoregie, M. Haehnel, J. Maier, G. Bringmann, T. B. Marder, ACS Catal., 2016, 6, 8332-8335.

[17] C. T. Yang, Z. Q. Zhang, H. Tajuddin, C. C. Wu, J. Liang, J. H. Liu, Y. Fu, M. Czyzewska, P. G. Steel, T. B. Marder, L. Liu, Angew. Chem. Int. Ed., 2012, 51, 528-532.

[18] T. C. Atack, R. M. Lecker, S. P. Cook, J. Am. Chem. Soc., 2014, 136, 9521-9523.

[19] A. S. Dudnik, G. C. Fu, J. Am. Chem. Soc., 2012, 134, 10693-10697.

[20] J. Hu, H. Sun, W. Cai, X. Pu, Y. Zhang, Z. Shi, J. Org. Chem., 2016, 81, $14-24$.

[21] A. Giroux, Tetrahedron Lett., 2003, 44, 233-235.

[22] R. B. Bedford, P. B. Brenner, E. Carter, T. Gallagher, D. M. Murphy, D. R. Pye, Organometallics, 2014, 33, 5940-5943.

[23] K. Endo, T. Ohkubo, M. Hirokami, T. Shibata, J. Am. Chem. Soc., 2010, 132, 11033-11035.

[24] K. Endo, T. Ohkubo, T. Shibata, Org. Lett., 2011, 13, 3368-3371.

[25] L. C. Cui, Z. Q. Zhang, X. Lu, B. Xiao, Y. Fu, RSC Adv., 2016, 6, 51932-51935.

[26] L. Mao, K. J. Szabó, T. B. Marder, Org. Lett., 2017, 19, 1204-1207.

[27] Z. C. Cao, F. X. Luo, W. J. Shi, Z. J. Shi, Org. Chem. Front., 2015, 2, 1505-1510.

[28] S. H. Cho, J. F. Hartwig, J. Am. Chem. Soc., 2013, 135, 8157-8160.

[29] M. A. Larsen, C. V. Wilson, J. F. Hartwig, J. Am. Chem. Soc., 2015, 137, 8633-8643.

[30] W. N. Palmer, J. V. Obligacion, I. Pappas, P. J. Chirik, J. Am. Chem. Soc., 2016, 138, 766-769.

[31] A. J. MacNair, C. R. P. Millet, G. S. Nichol, A. Ironmonger, S. P. Thomas, ACS Catal., 2016, 6, 7217-7221.

[32] J. V. Obligacion, P. J. Chirik, Org. Lett., 2013, 15, 2680-2683.

\section{Graphical Abstract}

Chin. J. Catal., 2018, 39: 1725-1729 doi: 10.1016/S1872-2067(18)63139-0

Cu-catalyzed deoxygenative gem-hydroborylation of aromatic aldehydes and ketones to access benzylboronic esters

Lu Wang, Wei Sun, Chao Liu*

Lanzhou Institute of Chemical Physics, Chinese Academy of Sciences;

University of Chinese Academy of Sciences

A novel copper-catalyzed deoxygenative gem-hydroborylation of aromatic aldehydes and ketones has been developed. This direct and operationally simple protocol provides an effective approach for the synthesis of a variety of primary and secondary benzylboronates, in which broad functional group tolerance was presented. Widely available $\mathrm{B}_{2} \mathrm{pin}_{2}$ was used as the boron source and alcoholic proton was applied as the hydride source.

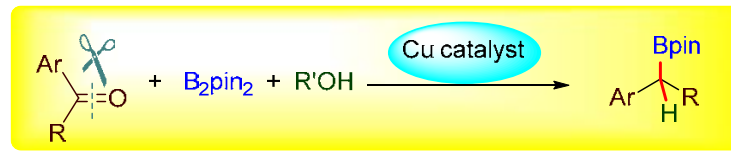


[33] M. L. Scheuermann, E. J. Johnson, P. J. Chirik, Org. Lett., 2015, 17, 2716-2719.

[34] X. Chen, Z. Cheng, Z. Lu, Org. Lett., 2017, 19, 969-971.

[35] D. Noh, H. Chea, J. Ju, J. Yun, Angew. Chem. Int. Ed., 2009, 48, 6062-6064.

[36] J. Peng, J. H. Docherty, A. P. Dominey, S. P. Thomas, Chem. Commun., 2017, 53, 4726-4729.

[37] J. Huang, W. Yan, C. Tan, W. Wu, H. Jiang, Chem. Commun., 2018, $54,1770-1773$.

[38] H. Li, L. Wang, Y. Zhang, J. Wang, Angew. Chem. Int. Ed., 2012, 51, 2943-2946.

[39] D. Shi, L. Wang, C. Xia, C. Liu, Angew. Chem. Int. Ed., 2018, 57, 10318-10322.

[40] L. Wang, T. Zhang, W. Sun, Z. He, C. Xia, Y. Lan, C. Liu, J. Am. Chem. Soc., 2017, 139, 5257-5264.

[41] A. G. Campaña, R. E. Estévez, N. Fuentes, R. Robles, J. M. Cuerva, E. Buñuel, D. Cárdenas, J. E. Oltra, Org. Lett., 2007, 9, 2195-2198.

[42] T. Bolaño, M. A. Esteruelas, M. P. Gay, E. Oñate, I. M. Pastor, M. Yus,
Organometallics, 2015, 34, 3902-3908.

[43] S. P. Cummings, T. N. Le, G. E. Fernandez, L. G. Quiambao, B. J. Stokes, J. Am. Chem. Soc., 2016, 138, 6107-6110.

[44] W. Ding, Q. Song, Org. Chem. Front., 2016, 3, 14-18.

[45] H. Lu, Z. Geng, J. Li, D. Zou, Y. Wu, Y. Wu, Org. Lett., 2016, 18, 2774-2776.

[46] D. P. Ojha, K. Gadde, K. R. Prabhu, Org. Lett., 2016, 18, 5062-5065.

[47] Q. Xuan, Q. Song, Org. Lett., 2016, 18, 4250-4253.

[48] W. Kong, Q. Wang, J. Zhu, Angew. Chem. Int. Ed., 2017, 56, 3987-3991.

[49] Q. Xuan, C. Zhao, Q. Song, Org. Biomol. Chem., 2017, 15, $5140-5144$.

[50] M. L. McIntosh, C. M. Moore, T. B. Clark, Org. Lett., 2010, 12, 1996-1999.

[51] H. Zhao, M. Tong, H. Wang, S. Xu, Org. Biomol. Chem., 2017, 15, 3418-3422.

[52] D. S. Laitar, E. Y. Tsui, J. P. Sadighi, J. Am. Chem. Soc., 2006, 128, 11036-11037.

\title{
铜催化芳香醛和酮的氢嗍化转化合成苄基硼酸酯类化合物
}

\author{
王 露 ${ }^{\mathrm{a}}$, 孙 威 ${ }^{\mathrm{a}, \mathrm{b}}$, 刘 超 ${ }^{\mathrm{a}, *}$ \\ $\mathrm{a}$ 中国科学院兰州化学物理研究所苏州研究院, 羰基合成与选择氧化国家重点实验室, 甘肃兰州 730000 \\ $\mathrm{b}$ 中国科学院大学, 北京 100049
}

\begin{abstract}
摘要: 有机硼化合物广泛应用于合成化学、药物化学以及材料化学等领域, 开发新颖实用的方法合成有机嗍化合物是重要 的研究领域. 在各种有机硼化合物中, 苄基嗍酸酯有着一些特有的性质, 例如活性相对较高, 可以有效地当作苄基化试剂 使用. 目前已有多种合成茮基硼酸酯的方法, 主要集中在茮基格氏试剂或者锂试剂的嗍化反应, 但是该方法底物兼容性较 差, 而且茮基格氏试剂或者锂试剂的制备比较困难. 随着催化反应的发展, 过渡金属(如Pd, $\mathrm{Cu}, \mathrm{Ni}, \mathrm{Fe}$ )催化茮基卤代物的硼 化反应及芳基卤代物和1,1-二嗍类化合物的偶联反应能够有效地合成这类化合物. 一级茮醇在钯或铜的催化作用下也可 以转化为苄基硼酸酯. 苄基 $\mathrm{C}-\mathrm{H}$ 键的催化嗍化是潜在的构建苄基硼酸酯的高原子经济性的方法, 但目前其选择性和反应活 性仍不高. 在无金属催化的条件下, 对甲苯磺酰腙类化合物与HBpin或 $\mathrm{B}_{2} \mathrm{pin}_{2}$ 发生 1,2 -金属迁移是合成茮基硼酸酯的有效方 法. 到目前为止, 虽然有很多种合成茮基嗍酸酯的方法, 但仍无法满足其合成需求, 因此开发新型的方法合成茮基硼酸酯 具有重要的意义.

本文开发了一种新型的铜催化芳香醛/酮类化合物的脱氧氢砋化转化体系. 使用廉价易得的铜作为催化剂, 叔丁醇钠 或者叔丁醇钾作为碱, 醇质子作为氢源, 在 $100{ }^{\circ} \mathrm{C}$ 的条件下, 芳香醛和芳香酮可直接转化成一级和二级茮基硼酸酯类化合 物, 该反应操作简单, 反应体系可以兼容多种官能团, 分离产率在 $21 \%-77 \%$ 之间. 反应机理方面, 该转化有两种可能的过 程, (1) 反应体系中首先生成1,1-偕二硼化合物, 该化合物在碱和EtOH的作用下发生脱硼质子解, 最终转化成茮基单硼化合 物; (2) 醇质子转化成负氢物种, 并与体系中的 $\alpha$-OBpin硼酸酯生成四配位硼, 发生1,2-迁移后得到目标产物.

为了验证上述两种反应途径的可行性, 我们进行了一系列的控制试验. 首先合成了苯乙酮的1,1-二硼化合物, 在催化 量碱与当量醇的作用下, 以 $99 \%$ 的收率得到了脱嗍质子解的产物, 说明 $1,1-二$ 二硼化合物可以在反应体系中转化成茮基单硼 化合物. 以苯甲酫作为原料合成了 $\alpha-O B$ pin硼酸酯, 首先将其投入到甲醇、叔丁醇钠和 $\mathrm{B}_{2} \mathrm{pin}_{2}$ 的体系中, 最终得到了 $47 \%$ 的 芐基单嗍; 同时将 $\alpha$-OBpin硼酸酯投入到HBpin与叔丁醇钠的体系中, 得到了 $57 \%$ 的茮基单硼化合物, 说明第二种反应过程 通过1,2-迁移得到目标产物也是可行的. 在当前的实验条件下, 两种反应路径都是可能的.
\end{abstract}

关键词: 均相催化; 铜催化; 脱氧氢硼化; 芳香醛; 芳香酮

收稿日期: 2018-06-13. 接受日期: 2018-07-15. 出版日期: 2018-11-05.

*通讯联系人. 电子信箱: chaoliu@licp.cas.cn

基金来源：国家自然科学基金(91745110, 21673261, 21603245, 21633013, 21703265); 中科院兰州化物所“特聘人才”计划; 中科院 青年促进会(2018458); 中国化学会青年人才托举工程项目; 中科院“西部之光”人才项目.

本文的电子版全文由Elsevier出版社在ScienceDirect上出版(http://www.sciencedirect.com/science/journal/18722067). 